\title{
PENGARUH UKURAN PERUSAHAAN, HASIL INVESTASI, DAN PROFITABILITAS TERHADAP SOLVABILITAS ASURANSI SYARIAH DI INDONESIA PERIODE 2012-2016
}

\author{
Samiari Ambarwati \\ Program Studi Ekonomi Islam, Universitas Airlangga \\ Email: samiari.ambarwati-2014@feb.unair.ac.id \\ Fatin Fadhilah Hasib \\ Departemen Ekonomi Syariah, Universitas Airlangga \\ Email: fatin.fadhilah@feb.unair.ac.id
}

ARTICLE HISTORY

Received:

22 September 2018

Accepted:

29 Desember 2018

Online available:

31 Desember 2018

Keywords:

Company Size, Invesment Return, Profitability,

Solvency, Islamic

Insurance

\section{Kata Kunci:}

Ukuran Perusahaan, Hasil Investasi,

Profitabilitas,

Solvabilitas,

Asuransi Syariah
ABSTRACT

The purpose of this study is to determine the effect of partial and simultaneous Company Size, Investment Return, and Profitability on Solvency with proxy of RBC at Sharia Insurance in Indonesia period 2012-2016. This study uses a quantitative approach. Sampling technique is purposive sampling and there were 17 sharia general insurance and sharia life insurance company in Indonesia as subject of research. Analysis technique used is panel data regression by using Fixed Effect Model (FEM).

The results of this study indicate that simultaneously company size, investment return, and profitability significantly influence the solvency of Takaful insurance in Indonesia. And partially variable of company size have positive and significant influence, variable investment return has no significant effect, and variable of profitability has no significant effect to solvency of sharia life insurance in Indonesia period 2012-2016.

\section{ABSTRAK}

Tujuan dari penelitian ini adalah untuk mengetahui pengaruh Ukuran Perusahaan, Hasil Investasi dan Profitabilitas terhadap Solvabilitas Asuransi Syariah di Indonesia periode 2012-2016 secara parsial dan simultan. Penelitian ini menggunakan pendekatan kuantitatif. Teknik pengambilan sampel adalah dengan purposive sampling dan didapatkan 17 perusahaan asuransi umum maupun asuransi jiwa syariah di Indonesia sebagai subjek penelitian. Teknik analisis yang digunakan adalah regresi dan menggunakan data panel dengan jumlah observasi 85 . Pendekatan yang digunakan 
adalah Fixed Effect Model (FEM)

Hasil Penelitian ini menunjukkan bahwa ukuran perusahaan, hasil investasi, dan profitabilitas secara simultan berpengaruh signifikan terhadap solvabilitas dengan persamaan $\mathrm{RBC}=-4,42541+$ 0,41850 size $+0,04616$ invest $+0,03370$ ROE. Ukuran perusahaan secara parsial berpengaruh positif dan signifikan terhadap solvabilitas. Sedangkan hasil investasi dan profitabilitas tidak berpengaruh signifikan pada $\alpha 0.05$ (5\%) terhadap solvabilitas asuransi syariah di Indonesia periode 2012-2016.

\section{PENDAHULUAN}

Manusia selalu dihadapkan pada berbagai persoalan hidup yang didalamnya mengandung berbagai kemungkinan risiko yang harus dihadapi, baik yang bersifat material maupun yang bersifat spiritual. Di antara berbagai kemungkinan risiko tersebut, risiko yang bersifat material cenderung lebih diperhatikan oleh manusia modern saat ini. Keberadaan perusahaan asuransi syariah di Indonesia mampu menarik minat masyarakat muslim di Indonesia. Kebutuhan akan lembaga keuangan syariah bertambah kuat bersamaan dengan berkembangnya sektor industri jasa keuangan bank dan non-bank. Bisnis keuangan syariah pada saat ini dapat dikatakan sebagai bisnis yang memiliki prospek bagus (Hasib dan Akbar, 2017). Selain karena mayoritas (80\%) penduduk Indonesia beragama Islam, juga karena konsep asuransi syariah dinilai lebih menguntungkan dengan adanya prinsip risk sharing.

Meskipun industri asuransi syariah mengalami perkembangan, akan tetapi hal ini belum bisa menyaingi perusahaan asuransi konvensional dari segi pangsa pasar. Penetrasi asuransi syariah di industri nasional periode 2016 yang masih rendah yakni pada angka 0,098\%. Sedangkan Asuransi Konvensional mencapai 99,902\%. Menurut Hasbi (2013) kondisi penetrasi yang rendah mengindikasi adanya masalah instrumen keuangan berbasis syariah. Terdapat dua faktor kemungkinan penyebab masalah tersebut. Faktor pertama disebabkan produk asuransi syariah tidak menarik. Faktor kedua karena kinerja perusahaan asuransi syariah yang rendah sehingga masyarakat masih belum percaya untuk berasuransi berbasis syariah. Menurut Hasib dan Husein (2016) salah satu indikator utama yang dijadikan dasar penilaian kesehatan adalah laporan keuangan. Oleh sebab itu asuransi syariah harus melakukan perbaikan diantaranya dengan menjaga kinerja keuangan. Menjaga kinerja keuangan dapat dilakukan dengan cara menjaga nilai solvabilitas. 
Menjaga nilai solvabilitas merupakan hal penting dalam asuransi syariah. Hal ini terlihat dengan dikeluarkannya peraturan yang mengatur kesehatan keuangan asuransi syariah No: 11/PMK/010/2011 yang menetapkan tingkat solvabilitas asuransi syariah paling rendah $30 \%$ dari dana yang diperlukan untuk mengantisipasi risiko kerugian yang mungkin timbul akibat deviasi dalam pengelolaan kekayaan dan kewajiban. Pada tahun 2016 terdapat kasus Asuransi Takaful Umum yang dibekukan oleh Otoritas Jasa Keuangan (OJK). Dana yang terdapat diperusahaan bisa disebut dana Qardh. Qardh adalah pinjaman dana dari perusahaan kepada dana tabarru' dalam rangka menanggulangi ketidakcukupan kekayaan dana tabarru' untuk membayar santunan/klaim kepada peserta (Safitri, 2016). Pada saat dibekukan perusahaan tersebut berada pada kondisi tingkat solvabilitasnya mendekati batas minimum solvabilitas yaitu sebesar 33\%. Selain itu perusahaan tersebut juga berada dalam kondisi tidak bertambahnya rasio modal dibandingkan dengan klaim yang harus dibayar.

Seperti yang tercantum dalam surat Al-Luqman (31):34,

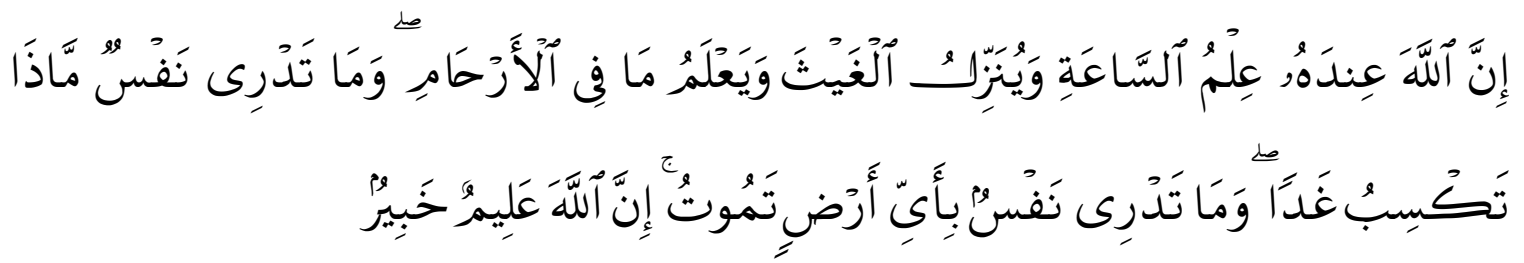

'inna allāha 'indahu 'ilmu as-sā'ati wa yunazzilu al-gayṡa wa ya'lamu mā fí al'arhāmi wa mā tadrī nafsun mā żā taksibu gadān wa mā tadrī nafsun bi 'ayyi 'ardin tamūtu 'inna allāha 'alīmun khabìru.

Artinya: "Sesungguhnya Allah, hanya pada sisi-Nya sajalah pengetahuan tentang hari Kiamat; dan Dia-lah yang menurunkan hujan, dan mengetahui apa yang ada dalam rahim dan tiada seorangpun yang dapat mengetahui (dengan pasti) apa yang akan diusahakannya besok. Dan tiada seorangpun yang dapat mengetahui di bumi mana Dia akan mati. Sesungguhnya Allah Maha mengetahui lagi Maha Mengenal"

Penafsiran ayat Al-Quran: Menurut Shihab (2009:13) pada Surat Al-Luqman ayat 34, sesungguhnya hanya pada Allah kemutlakan pengetahuan tentang hari kiamat. Tidak ada yang mengetahui selain-Nya dan Dia pula yang menurunkan hujan pada waktu yang telah ditentukan-Nya. Dialah yang mengetahui jenis kelamin bayi yang ada di rahim serta kekurangan dan kesempurnaannya. Tak seorang pun, baik yang taat maupun yang jahat, yang tahu apa yang akan diperbuatnya esok hari, baik atau buruk. Tidak ada seorang pun 
yang mengetahui di bumi mana dia menemui ajalnya karena sesungguhnya hanya Allah yang memiliki kesempurnaan ilmu tentang segala sesuatu.

Penulis tertarik untuk menggunakan variabel eksogen ukuran perusahaan, hasil investasi, dan profitabilitas. Berdasar penelitian-penelitian sebelumnya penulis ingin mengetahui dengan variabel tersebut apakah faktor-faktor tersebut berpengaruh terhadap kinerja keuangan asuransi syariah yang terdaftar di Otoritas Jasa Keuangan (OJK). Pemilihan asuransi syariah sebagai objek sampel karena asuransi syariah masih tergolong pemain baru dalam industri asuransi dibandingkan dengan asuransi konvensional yang telah lama berdiri sehingga masih sedikit penelitian asuransi syariah dibandingkan asuransi konvensional. Pemilihan periode pengamatan 2012 hingga 2016 dipilih karena pada tahun tersebut laporan keuangan tersedia pada website resmi asuransi syariah.

\section{LANDASAN TEORI}

Dasar Hukum Asuransi Syariah menurut Widyaningsih (2005:236) beberapa dasar hukum yang dapat digunakan sebagai acuan dalam pelaksanaan asuransi syariah sebagai berikut :

\section{Al-Qur'an}

Allah SWT telah menetapkan semua aspek kehidupan manusia melalui Al-Qur'an dan Hadist yang disampaikan oleh Nabi Muhammad SAW. Asuransi juga merupakan salah satu aspek kehidupan yang telah diatur oleh Allah SWT.

\section{As-Sunnah (Hadits)}

Hadits Rasulullah SAW yang merupakan landasan dalam asuransi syariah adalah sebagai berikut: (Ali, 2008:127) Diriwayatkan dari Abu Musa RA, Rasulullah SAW bersabda: Seorang mukmin terhadap mukmin yang lain adalah seperti sebuah bangunan di mana sebagiannya menguatkan sebagian yang lain.

\section{Pendapat Ulama}

Para ahli hukum hukum Islam (fuqaha) sepenuhnya sadar bahwa status hukum syariah belum pernah ditetapkan oleh pemikir hukum Islam di masa lalu. Ide asuransi yang dimaksud, muncul saat ada akulturasi budaya antara Islam dan budaya Eropa. Namun, ketika diteliti melalui studi mendalam ditemukan bahwa asuransi tersebut terkandung di dalamnya maslahat sehingga para ahli hukum Islam mengadopsi manajemen asuransi berdasarkan prinsip syariah. 


\section{Perudang-Undangan}

Undang-undang dan peraturan tentang asuransi di Indonesia diatur di beberapa tempat, termasuk Undang-undang tentang Hukum Perdagangan (KUHD), UU No. 2 tahun 1992 tentang Usaha Perasuransian.

Menurut Janwari (2005:53-58), asuransi syariah terdiri dari dua jenis yaitu:

1. Asuransi syariah umum (asuransi kerugian)

Asuransi syariah umum adalah asuransi syariah yang memberi perlindungan dalam menghadapi kecelakaan atau bencana atas harta milik peserta asuransi syariah.

2. Asuransi Syariah keluarga (asuransi jiwa)

Asuransi syariah keluarga adalah asuransi syariah yang memberikan perlindungan dalam musibah kematian dan kecelakaan atas diri peserta asuransi syariah. Asuransi umum syariah adalah harta yang dimiliki peserta asuransi sedangkan yang diasuransikan dalam asuransi syariah keluarga adalah jiwa peserta asuransi itu sendiri.

\section{METODE PENELITIAN}

Pendekatan yang digunakan dalam penelitian ini adalah pendekatan kuantitatif. Penelitian ini akan membuktikan pengaruh ukuran perusahaan, hasil investasi, dan profitabilitas terhadap solvabilitas asuransi syariah di Indonesia periode 2012-2016. Di dalam penelitian ini, peneliti menggunakan analisis regresi data panel sebab peneliti ingin mengetahui sejauh mana variabel eksogen mempengaruhi variabel endogen. Dalam penelitian ini yang menjadi variabel endogen adalah Solvabilitas Asuransi Syariah dan variabel eksogennya adalah Ukuran Perusahaan, Hasil Investasi, dan Profitabilitas.

Ukuran perusahaan menurut Yulia (2013) umumnya dapat diartikan sebagai perbandingan ukuran atau jumlah aset yang dimiliki oleh perusahaan. Ukuran perusahaan dalam penelitian ini terlihat berdasarkan jumlah total aset yang dimiliki perusahaan (Kusuma, 2013). Ukuran perusahaan juga mempengaruhi solvabilitas perusahaan asuransi karena ukuran perusahaan menunjukkan kekuatan perusahaan asuransi dalam menanggung risiko.

Rasio hasil investasi adalah rasio yang digunakan untuk mengetahui kesehatan perusahaan asuransi (Ningrum, 2014). Rasio hasil investasi dapat digunakan untuk menilai kebijaksanaan investasi yang dijalankan oleh perusahaan asuransi. Menurut Palupy (2006), perusahaan asuransi pada dasarnya memiliki kebutuhan penghasilan 
investasi yang tinggi dari aset-aset investasi yang mereka miliki. Pengelolaan investasi yang baik akan dapat mengakomodasi tingkat risiko investasi yang dapat ditoleransi oleh perusahaan dengan hasil investasi yang sesuai, yang pada akhirnya dapat meningkatkan kinerja perusahaan.

Perusahaan asuransi yang memiliki tingkat profitabilitas tinggi dapat menjadi sumber pendanaan internal yang berguna untuk menopang di dalam pertanggungan atas risiko yang ditanggung (Haan dan Kakes, 2010). Profitabilitas perusahaan asuransi juga menjadi variabel yang signifikan terhadap pengurangan risiko sebuah perusahaan asuransi mengalami keadaan insolvency (Agner, 2001).

Solvabilitas menunjukkan kemampuan perusahaan untuk memenuhi semua kewajiban finansialnya jika telah dilikuidasi (Bambang, 1995). Solvabilitas atau leverage untuk mengukur bagaimana total aset yang dibiayai oleh pemiliknya. Dalam penelitian ini solvabilitas diukur dengan menggunakan standar yang digunakan di Indonesia dalam perhitungannya, yaitu menggunakan metode Risk-based Capital (RBC).

Kriteria sampel yang digunakan dalam penelitian adalah sebagai berikut :

1. Perusahaan Asuransi syariah di Indonesia yang terdaftar di Otoritas Jasa Keuangan.

2. Perusahaan Asuransi yang masih beroperasi secara syariah pada tahun 20122016.

3. Memilki laporan keuangan tahunan secara kontinyu dalam satuan mata uang rupiah yang dipublikasikan selama periode 2012-2016.

Jumlah asuransi syariah yang terdaftar pada tahun 2016 sebanyak 58 perusahaan. Berdasarkan kriteria tersebut selama periode penelitian, perusahaan yang memenuhi kriteria sebanyak 17 perusahaan asuransi syariah pada periode penelitian 2012-2016, sehingga diperoleh observasi sebanyak 85.

\section{HASIL DAN PEMBAHASAN}

Dalam penelitian ini, teknik analisis yang dilakukan menggunakan metode analisis data panel dengan tahap-tahap sebagai berikut:

1. Uji Asumsi Klasik

Menurut Basuki dan Prawoto (2016:297) uji asumsi klasik yang digunakan dalam regresi data panel terdiri dari uji normalitas, uji multikolinieritas dan uji heteroskedastisitas. 
1).Uji Normalitas

Tabel 1

Uji Normalitas

Kolmogorov-Smirnov Z $\quad 0.712$

Asympi Sig. $\quad 0.691$

Nilai signifikan 0,691 dengan hasil tersebut dapat disimpulkan bahwa dalam penelitian ini data terditribusi normal.

2) Uji Multikolinieritas

Tabel 2

Uji Multikolinearitas

\begin{tabular}{clc}
\hline & VIF & $\mathbf{1 / V I F}$ \\
\hline Size & 1.11 & 0.901897 \\
Invest & 1.00 & 0.996517 \\
ROE & 1.11 & 0.900339 \\
\hline
\end{tabular}

Diperoleh nilai VIF bagi masing-masing variabel kurang dari 10 dan nilai 1/VIF bagi masing-masing variabel lebih dari 0.10 . Hal ini menandakan bahwa dalam penelitian ini tidak ada gejala mulikolinearitas.

3) Uji Heteroskedastisitas

Tabel 3

Uji Heteroskedastisitas

Prob>chi 0,0860

Nilai signifikan 0,0860 dengan hasil tersebut dapat disimpulkan bahwa dalam penelitian ini tidak terjadi heteroskedastisitas pada variabel independen.

2. Pemilihan Model Estimasi Data Panel

1) Uji Chow 
Pengaruh Ukuran Perusahaan, Hasil Investasi, Dan Profitabilitas Terhadap....

Tabel 4

Uji Chow

Prob>chi 0,0001

Berdasarkan tabel uji Chow diperoleh probabilitas cross-section $F$ sebesar 0,0001 . Angka ini menunjukkan tingkat signifikansi dibawah 0,05 (5\%) sehingga $\mathrm{HO}$ ditolak dan $\mathrm{H} 1$ diterima. Hasil tersebut dapat disimpulkan bahwa fixed effect model merupakan model yang tepat.

2) Uji Hausman

Tabel 5

Uji Hausman

\begin{tabular}{ll}
\hline Prob>chi2 & 0,0451 \\
\hline
\end{tabular}

Berdasarkan tabel uji Hausman diperoleh probabilitas pada chi-squares sebesar 0,0451 . Angka ini menunjukkan tingkat signifikansi dibawah 0,05 (5\%) sehingga HO ditolak. Hasil tersebut dapat disimpulkan bahwa fixed effect model merupakan model yang tepat.

Tabel 6

Hasil Fixed Effect Model

\begin{tabular}{cccc}
\hline Variabel & \multicolumn{3}{c}{ Model Regresi } \\
\hline \multirow{2}{*}{ Independen } & Koefisien & Sig & Kesimpulan \\
\cline { 2 - 4 } Size & 0.4185047 & 0.000 & Signifikan \\
Invest & 0.461607 & 0.737 & Tidak signifikan \\
ROE & 0.33709 & 0.919 & Tidak signifikan \\
Cons & -4.425418 & 0.000 & \\
R Square & 0.6128 & & \\
F statistic & 3.73 & & \\
F sig & 0.0001 & & \\
& & & \\
\hline RBC $=-4,425418+0.4185047$ size+0,0461607invest+0,033709ROE
\end{tabular}

$\mathrm{RBC}=-4,425418+0.4185047$ size $+0,0461607$ invest+0,033709ROE 


\section{Uji Hipotesis}

1) Uji Simultan (Uji F)

Tabel 7

Uji Simultan

\begin{tabular}{cc}
\hline F- Statistic & 3.73 \\
\hline Prob (F-statistic) & 0.0001
\end{tabular}

Berdasarkan tabel di atas hasil probabilitas $\mathrm{F}$ statistik sebesar 0,0001 lebih kecil dari tingkat signifikansi 0,05 (5\%) maka HO ditolak dan H1 diterima. Hipotesis yang menyatakan ada pengaruh secara simultan antara ukuran perusahaan, hasil investasi, dan profitabilitas secara simultan berpengaruh terhadap RBC asuransi syariah di Indonesia dapat diterima.

2) Uji Parsial (Uji T)

Tabel 8

Uji Parsial

\begin{tabular}{cccc}
\hline Variabel & Probability & A & Keterangan \\
\hline Size & 0.000 & & Nilai prob $<\alpha: \mathrm{H}_{0}$ ditolak \\
Invest & 0.737 & 0,05 & Nilai prob $>\alpha: \mathrm{H}_{0}$ diterima \\
ROE & 0.919 & & Nilai prob $>\alpha: \mathrm{H}_{0}$ diterima \\
\hline
\end{tabular}

1 Nilai uji t variabel ukuran perusahaan ukuran perusahaan berpengaruh positif secara signifikan terhadap solvabilitas.

2 Nilai uji $t$ variabel hasil investasi tidak berpengaruh secara signifikan terhadap solvabilitas.

3 Nilai uji $\mathrm{t}$ variabel profitabilitas tidak berpengaruh secara signifikan terhadap solvabilitas.

3) Uji Koefisien Determinasi (R Square)

Pada Tabel 6 diatas maka diperoleh nilai R-Squared sebesar 0,6128 atau 61,28\%. Angka tersebut menunjukkan bahwa keragaman nilai variabel solvabilitas dapat dijelaskan oleh variabel ukuran perusahaan, hasil investasi, dan 
Pengaruh Ukuran Perusahaan, Hasil Investasi, Dan Profitabilitas Terhadap....

profitabilitas sebesar $61,28 \%$, sedangkan sisanya $38,72 \%$ dijelaskan oleh variabel lain yang tidak termasuk dalam penelitian ini.

4. Pembahasan

1. Pengaruh Ukuran Perusahaan terhadap Solvabilitas

Hasil penelitian ini menunjukkan ukuran perusahaan berpengaruh signifikan terhadap solvabilitas perusahaan. Hasil uji statistik $\mathrm{t}$ menunjukkan bahwa nilai signifikansi ukuran perusahaan 0.000 atau lebih kecil dari 0.05 yang berarti ukuran perusahaan berpengaruh terhadap tingkat solvabilitas perusahaan asuransi syariah periode 2012-2016. Hal ini berarti setiap ukuran perusahaan mengalami peningkatan atau penurunan maka berpengaruh terhadap tingkat solvabilitas asuransi syariah.

Penelitian ini sesuai dengan penelitian yang dilakukan oleh Kusuma (2013) dan Joo (2013) yang menemukan bahwa ukuran perusahaan berpengaruh terhadap tingkat solvabilitas perusahaan asuransi. Menurut Kusuma (2013), ukuran perusahaan mempengaruhi solvabilitas perusahaan asuransi karena ukuran perusahaan menunjukkan kekuatan perusahaan asuransi dalam menanggung risiko. Dalam teori hukum bilangan besar (law of large number) dalam dunia asuransi adalah semakin banyak orang yang bergabung dengan asuransi, maka kemungkinan besarnya kerugian akan mendekati kerugian yang diperkirakan.

2. Pengaruh Hasil Investasi terhadap Solvabilitas

Dalam penelitian ini hasil investasi tidak signifikan berpengaruh terdahap solvabilitas. Menurut Joo (2013) ketepatan investasi akan memberikan keuntungan besar bagi perusahaan yang akan memiliki efek positif pada tingkat solvabilitas. Dapat diasumsikan hasil investasi yang didapat perusahaan asuransi syariah di Indonesia kurang mendapat keuntungan atau investasi yang dilakukan kurang banyak atau kurang tepat sehingga hasil investasi yang dihasilkan memberikan keuntungan kecil yang menyebabkan hasil investasi tidak signifikan berpengaruh terhadap solvabilitas. Di Indonesia perusahaan asuransi syariah lebih mengutamakan kecukupan modal untuk menutupi kewajiban kewajibanya. Kecukupan modal diperoleh dari rmodal sendiri atau pinjaman dari bank maupun lembaga keuangan lainnya, sehingga hasil investasi tidak signifikan berpengaruh terhadap solvabilitas perusahaan asuransi syariah di Indonesia. Penelitian ini sesuai dengan penelitian yang dilakukan oleh (Joo, 2013). 


\section{Pengaruh Profitabilitas terhadap Solvabilitas}

Dalam penelitian ini profitabilitas tidak signifikan berpengaruh terdahap solvabilitas asuransi syariah di Indonesia. Menurut Han dan Kakes (2010), perusahaan asuransi yang memiliki tingkat profitabilitas tinggi dapat menjadi sumber pendanaan internal yang berguna untuk menopang di dalam pertanggungan atas risiko yang ditanggung. Bisa diasumsikan bahwa keuntungan yang didapat perusahaan asuransi syariah di Indonesia kurang tinggi sehingga dalam menutupi kewajiban kewajibannya lebih diutamakan dari kecukupan modal. Kecukupan modal asuransi syariah di Indonesia dapat diperoleh dari modal sendiri atau pinjaman dari bank maupun lembaga keuangan lainnya. Sehingga profitabilitas tidak signifikan berpengaruh terhadap solvabilitas asuransi syariah di Indonesia. Penelitian ini sesuai dengan penelitian yang dilakukan oleh (Kusuma, 2013) dan (Tarigan dan Mahfud, 2015).

4. Pengaruh Ukuran Perusahaan, Hasil Investasi, dan Profitabilitas, terhadap Solvabilitas

Koefisien determinasi (R2) menunjukkan nilai 0,6128 atau 61.28\%, Artinya sebesar $61.28 \%$ dapat dijelaskan oleh variabel eksogen penelitian yaitu Ukuran Perusahaan, Hasil Investasi, dan Profitabilitas sedangkan sisanya $38.72 \%$ dijelaskan oleh variabel lain diluar variabel eksogen yang digunakan pada penelitian ini, dengan demikian hipotesis pada penelitian ini bahwa variabel eksogen ukuran perusahaan, hasil investasi, dan profitabilitas secara simultan berpengaruh terhadap solvabilitas diterima. Secara keseluruhan variabel eksogen secara simultan memiliki pengaruh terhadap solvabilitas, yang artinya apabila variabel eksogen mengalami perubahan maka akan berdampak pada perubahan solvabilitas.

\section{SIMPULAN}

Berdasarkan hasil perhitungan $F$ menunjukkan variabel eksogen Ukuran Perusahaan, Hasil Investasi, dan Profitabilitas secara simultan berpengaruh signifikan terhadap solvabilitas dengan dengan nilai solvabilitas 0,0001 dengan $\alpha$ 0,05 dengan demikian hipotesis penelitian ini terbukti karena $\mathrm{H} 4$ diterima dari $\mathrm{HO}$ ditolak. Ukuran Perusahaan secara parsial berpengaruh positif signifikan terhadap solvabilitas. Hasil Investasi tidak berpengaruh signifikan secara parsial terhadap solvabilitas. Profitabilitas tidak berpengaruh signifikan secara parsial terhadap solvabilitas. 
Pengaruh Ukuran Perusahaan, Hasil Investasi, Dan Profitabilitas Terhadap....

\section{DAFTAR PUSTAKA}

Abduh, M., \& Zein Isma, S. N. (2017). Economic and market predictors of solvency of family takaful in Malaysia. Journal of Islamic Accounting and Business Research, 8(3), 334-344.

Abdullah, Amrin. (2009). Bisnis, Ekonomi, Asuransi, dan Keuangan. Bandung: PT Grasindo

Mehari, D., \& Aemiro, T. (2013). Firm Specific Factors That Determine Insurance Companies'performance In Ethiopia. European Scientific Journal, ESJ, 9(10).

Agner, Sawir. (2001). Analisis Kinerja Keuangan \& Perencanaan Keuangan Perusahaan. Jakarta: PT.Gramedia Pustaka Utama

Ahmed, N. (2010). Determinants Of Performance: A Case Of Life Insurance Of Pakistan. European Jurnal of Economis, Finance And Administrative Sciences, 24(2), 7-12

Ali, Hasan. (2004). Asuransi dalam Perspektif Hukum Islam. Jakarta: Prenada Media.

Ali, Zainuddin. (2008). Hukum Asuransi Syariah, Jakarta: Sinar Grafika

Almajali, A. Y., Alamro, S. A., \& Al-Soub, Y. Z. (2012). Factors affecting the financial performance of Jordanian insurance companies listed at Amman Stock Exchange. Journal of Management research, 4(2), 266-289.

Andhayani. (2012). Asuransi Syariah. Jakarta: Elex Media Komputindo

Anshori, Muslich dan Iswati, Sri. (2009). Metodologi Penelitian Kuantitatif. Surabaya : Airlangga University Press (AUP)

Asosiasi Asuransi Syariah Indonesia. (2016). Sharia Insurance Economic Outlook 2016. Jakarta: Asosiasi Asuransi Syariah Indonesia

Bambang, Riyanto. (1995). Dasar-Dasar Pembelanjaan Perusahaan. Yogyakarta: BPFEYogyakarta.

Bambang. (1995). Dasar-Dasar Pembelanjaan Perusahaan. Yogyakarta: BPFE-Yogyakarta.

Basuki, Agus Tri dan Prawoto Nano. (2016). Analisis Regresi Dalam Penelitian Ekonomi \& Bisnis : Dilengkapi Aplikasi SPSS \& EVIEWS. Depok : PT Rajagrafindo Persada 